\title{
Capitalismo, Estado e política: notas a partir de Chasin e do Gramsci de Carlos Nelson Coutinho
}

\author{
Paulo Henrique Furtado de Araujo \\ Universidade Federal Fluminense (UFF)
}

Capitalismo, Estado e política: notas a partir de Chasin e do Gramsci de Carlos Nelson Coutinho Resumo: Este artigo parte do entendimento de que a construção teórica de Marx é uma ontologia materialista do ser social e que as categorias capital, Estado e política devem ser tratadas como categorias ontológicas. Baseia-se em Chasin e Coutinho, que põem no horizonte teórico e prático a superação da lógica do capital e da sua sociabilidade específica. Destaca, em Chasin, o desvelamento da ontonegatividade da política e a categoria de metapolítica. Posiciona-se criticamente em relação à leitura de Gramsci proposta por Coutinho, marcada por uma concepção ontopositiva da política e a algumas conclusões sobre o processo de transformação social e a perenidade da política. Por fim, assinala uma possível convergência entre as duas abordagens.

Palavras-chave: Capitalismo. Estado. Política. Marxismo. Ontologia.

\section{Capitalism, State and Policy: notes on Chasin and Gramsci from Carlos Nelson Coutinho}

Abstract: This article is based on the understanding that the theoretical construction of Marx is a materialist ontology of the social being and that the categories capital, State and politics must be treated as ontological categories. It is based on Chasin and Coutinho, who place on the theoretical and practical horizon a surpassing of capitalist logic and its specific sociability. It highlights in Chasin the unveiling of the ontonegativity of politics and the category of metapolitcs. It criticizes Coutinho's reading of Gramsci, which is marked by an ontopositive concept of politics and some conclusions about the process of social transformation and the perennation of politics. Finally, it indicates a possible convergence between the two approaches.

Keywords: Capitalism. State. Politics. Marxism. Ontology. 


\section{Introdução}

Este artigo explora o entendimento da necessidade ontológica do Estado na economia para a reprodução do capital, e procura pistas para o lugar da política na superação do Estado e do capital. Destaca algumas considerações sobre a categoria ontonegatividade da politicidade e a necessidade da metapolítica para a efetiva emancipação humana, tal como formulada por José Chasin, a partir de sua leitura dos textos de Marx. Em seguida, apresenta interpretação de Gramsci, dada por Coutinho, que formula uma estratégia para a superação da formação histórica que melhor permite a expansão do valor, destacando suas eventuais limitações frente ao constructo teórico marxiano. Por fim, contrapõe a interpretação de Coutinho às contribuições de Chasin.

\section{Concepção ontonegativa da politicidade de Chasin}

O Estado moderno é parte constituinte da base material da lógica expansionista do capital. A política como emanação dinâmica da luta pelo poder do Estado está subsumida à lógica do capital.

O termo "ontonegatividade da politicidade" foi forjado pelo filósofo marxista José Chasin ${ }^{1}$ e surge como resultado das escavações que o mesmo faz nos textos do Marx pré-marxiano (no período de 18411843, Marx encontrava-se ligado teoricamente às concepções filosóficas hegelianas, quando escreveu sua tese doutoral A diferença da natureza em Demócrito e Epicuro, e outros artigos da Gazeta Renana) e do Marx já marxiano em seus primeiros momentos e depois, quando escreve Para a crítica da filosofia do direito de Hegel - Introdução, Sobre a questão judaica, Crítica de Kreuznach, Glosas críticas marginais ao artigo 'O Rei da Prússia e a Reforma Social', Materiais preparatórios para a redação de A Guerra Civil na França etc.

Chasin, mantendo-se firmemente ancorado na perspectiva ontológica da sociabilidade humana, nos termos propostos pelo velho Lukács (1976; 1982), demonstra que Marx rompe com Hegel, com os jovens hegelianos e com Feuerbach no entendimento da politicidade. Inicialmente ele acreditava, como todos estes, que a política e o Estado eram a

[...] própria realização do humano e da sua racionalidade. Vertente para a qual 'estado' e 'liberdade' ou 'universalidade', 'civilização' ou 'hominização' se manifestam como determinações recíprocas, de tal forma que a politicidade é tomada como predicado intrínseco ao ser social e, nessa condição - enquanto atributo eterno da socialidade - reiterada sob modos diversos que, de uma ou de outra maneira, a conduziram à plenitude da estatização verdadeira na modernidade. Politicidade como qualidade perene, positivamente indissociável da autêntica entificação humana, portanto, constitutiva do gênero, de sorte que orgânica e essencial em todas as suas atualizações (CHASIN, 1995, p. 354).

Entretanto, depois, Marx evolui para uma posição radicalmente contrária, deflagrada - segundo ele próprio relata no Prefácio de 1859 de Para a crítica da economia política (MARX, 1986, p. 24) - quando se vê confrontado com a discussão sobre os chamados interesses materiais (deliberação do Parlamento Renano sobre o roubo de madeira etc.). Volta-se para uma revisão da filosofia do direito de Hegel e beneficia-se dos textos de Feuerbach publicados à época: as "Teses provisórias para a reforma da filosofia, escritas em abril de 42, mas só publicadas no Anedokta em fevereiro de 43, e Princípios da filosofia do futuro, editados em julho de 43" (CHASIN, 1995, p. 360) nas quais ocorria uma ruptura com o pensamento hegeliano.

A posição radicalmente diferente difundida por Marx põe a perspectiva ontológica como centro e guia de sua investigação. Agora interessa o homem em sua efetividade material, a sociabilidade decorrente da vida material-real do homem passa a ser a base para a intelecção do ser social. Assim, Marx renega o idealismo hegeliano, sua postura especulativa, logicista e abstrata da razão que se autorrealiza. Conforme Chasin (1995, p. 362),

[...] irrompe e domina agora, para não mais ceder lugar, a 'sociedade civil' - o campo da interatividade contraditória dos agentes privados, a esfera do metabolismo social - como demiurgo real que alinha o estado e as relações jurídicas.

Em Para a crítica da filosofia do direito de Hegel - Introdução, de 1844, pensado como introdução à Para a crítica da filosofia do direito ou em Crítica de Kreuznach, de 1843, Marx já faz a crítica da política, fazendo-a, segundo Chasin, perder altura e centralidade. 
Nas páginas finais de Para a crítica da filosofia do direito de Hegel - Introdução, Marx (2005, p. 154-156) deixa evidenciada a centralidade da revolução radical (ou social) para a emancipação global do homem, o início da realização das potencialidades inerentes ao homem, e o avanço do processo de hominização. $\mathrm{O}$ agente de tal processo é identificado

[...] numa classe da sociedade civil que não seja uma classe da sociedade civil, de um estamento que seja a dissolução de todos os estamentos, de uma esfera que possua caráter universal porque os seus sofrimentos são universais [...]; por fim, de uma esfera que não pode emancipar-se a si mesma nem se emancipar de todas as outras esferas da sociedade sem emancipá-las a todas - o que é, em suma, a 'perda total' da humanidade, portanto, só pode redimir-se a si mesma por uma 'redenção total' do homem. A dissolução da sociedade, como classe particular, é o 'proletariado’ (MARX, 2005, 155-156, grifos do autor)².

Em suma, agora Marx não deixa dúvida do seu distanciamento da revolução política stricto sensu, não se trata mais da constituição de um Estado ou de uma nova prática política mais perfeita, equilibrada ou ética ${ }^{3}$. Trata-se de iniciar a humanização do homem, de findar a pré-história humana e iniciar a verdadeira história.

Chasin (1995, p. 368, grifos do autor) entende a política como ontonegativa, pois não pertence à essência do ser social, sua presença é "extrínseca e contingente" e "circunstancial" em relação ao ser social. Ou seja, a política só é admitida

[...] enquanto predicado típico do ser social, apenas e justamente, na particularidade do longo curso de sua 'pré-história'. É no interior da intrincada trajetória dessa 'pré-história' que a politicidade adquire sua fisionomia plena e perfeita, sob a forma de poder político centralizado, ou seja, do Estado moderno.

Essa perspectiva marxiana é o antípoda da posição dominante (secularmente falando) que adota a perspectiva ontopositiva da política. Para esta perspectiva, a política é intrínseca ao ser social, sendo vista como a mais elevada espiritualmente ou mais relevante pragmaticamente, e isto desemboca na "indissolubilidade entre política e sociedade, a ponto de tornar quase impossível, até mesmo para a simples 'imaginação', um formato social que independa de qualquer forma de poder político" (CHASIN, 1995, p. 368). Para Marx, a emancipação humana implica na reintegração das

[...] forças sociais alienadas à política, ou seja, que ela só pode se realizar como reabsorção de energias próprias despidas da forma política, depuradas, exatamente, da crosta política sob a qual haviam se autoaprisionado e perdido (CHASIN, 1995, p. 368). ${ }^{4}$

Chasin prossegue lembrando que por toda a pré-história da humanidade temos formas de sociabilidade de pouca racionalidade, pouco evolvidas, nas quais a politicidade sempre se apresenta com seu irmão siamês, a propriedade privada dos meios de produção; uma é incapaz de viver sem a outra e só podem desaparecer como vivem: juntas. Daí, ele adita que o predicado da politicidade exige, de forma continuada, atos de poder. O que explica a atividade política enquanto necessidade nessas formas de sociabilidade e isto engloba tanto as atividades políticas que defendem quanto as que contestam o status quo.

Em se tratando de contestação consciente e que mira deliberadamente na emancipação humana, exige-se a prática de "uma política orientada pela superação da política, pois seu escopo é a reconversão e o resgate das energias sociais desnaturadas em vetores políticos". Ou seja, a determinação ontonegativa da politicidade - "fundamento da reflexão política de Marx" - coloca a necessidade da metapolítica, que é um:

[...] conjunto de atos de efetivação que não apenas se desembarace de formas particularmente ilegítimas e comprometidas de dominação política, para as substituir por outras supostas como melhores, mas que vá se desfazendo, desde o princípio, de toda e qualquer politicidade, à medida em que se eleva da aparência da política à essência social das lutas históricas concretas, à proporção em que promove a afloração e realiza seus objetivos humanos societários, os quais, em suma, têm naquela ultrapassagem, indissociável da simultânea superação da propriedade privada dos bens de produção, a condição de possibilidade de sua realização. Numa frase, a crítica marxiana da política, decifração da natureza da politicidade e de seus limites, é, por consequência, o deslocamento da estreiteza e insuficiência da 'prática política' enquanto atividade humana racional e universal, donde o salto metabólico ao encontro resolutivo da 'sociabilidade', essência do homem e de todas as formas de prática humana (CHASIN, 1995, p. 369, grifos do autor). 


\section{Hegemonia e guerra de posição: o Gramsci de Coutinho}

Boa parte da obra de Gramsci foi escrita no cárcere do fascismo italiano, por isto se encontra envolta numa linguagem que buscava despistar a censura fascista, mas há também as próprias dificuldades de sistematização do autor, como assinala Perry Anderson (1986).

Gramsci trata a categoria de sociedade civil de forma diferente ao tratamento dado por Marx. A sociedade civil (bürgliche Gesellschaft ou, ao pé da letra, sociedade burguesa), em Marx, é o terreno das relações de propriedade dadas pela lógica do capital, é o lugar do egoísmo e da luta de todos contra todos. O Estado moderno, como vimos, é uma exigência posta pelas características da sociedade civil, e esta, por sua vez, é posta pela lógica do capital.

Em Gramsci, sociedade civil também expressa a esfera das relações privadas (não estatal), o que inclui a economia. A diferença está em que agora a sociedade civil não diz respeito somente às necessidades individuais, mas inclui organizações sociais e traz em si a possibilidade (in potentia) da constituição da liberdade, da sociedade autorregulada. Na interpretação de Coutinho (1999, p. 121), a sociedade civil, em Gramsci, é a "portadora material da figura social da hegemonia, como esfera de mediação entre a infraestrutura econômica e o Estado [...]".

Coutinho (1999, p. 119-143) procura demonstrar que Gramsci, ao tratar das categorias sociedade civil e sociedade política - que perfazem o que ele chama de Estado em sentido ampliado e que Anderson (1986), ao analisar o trabalho de Gramsci, vai dizer que é a terceira tentativa presente nos Cadernos do cárcere de demonstrar a articulação entre sociedade civil e sociedade política - realiza um procedimento de concretização, de redução do nível de abstração, similar ao que Marx realiza em $O$ capital. Tal movimento foi possível porque Gramsci testemunhou a complexificação do ser social quanto ao desenvolvimento das organizações constitutivas da sociedade civil (aparelhos privados de hegemonia - partidos, sindicatos, igrejas, jornais etc.), que ocorreu no que ele chamou de sociedades ocidentais (adiante voltaremos à discussão sobre sociedades ocidentais e orientais). Coutinho adverte que Gramsci consegue captar um movimento histórico-ontológico, ou seja, existiria um movimento tendencial no ser social de uma situação na qual o Estado é tudo e há o predomínio da coerção em detrimento da sociedade civil, para uma situação na qual o Estado, ampliado, é o próprio equilíbrio entre coerção e consenso ou dominação e direção.

Coutinho parece, em alguns momentos, ter uma concepção ontopositiva da politicidade. Ainda que, de forma inteligente, procura determinar o conceito de política, de tal forma a não romper com a concepção marxiana da necessidade de superação/destruição do Estado e da política como pré-condição para o início da história humana. Defende que Gramsci apresenta dois sentidos para a categoria política: um "restrito" e outro "amplo". A política em seu sentido amplo

[...] identifica-se praticamente com liberdade, com universalidade, com toda forma de práxis que supera a mera recepção passiva ou a manipulação de dados imediatos (passividade e manipulação que caracterizam boa parte da práxis técnico-econômica e da práxis cotidiana em geral) e se orienta conscientemente para a totalidade das relações subjetivas e objetivas. E, segundo essa acepção, é justo dizer com Gramsci - pois isto corresponde a um fato ontológico real - que todas as esferas do ser social são atravessadas pela prática política, contêm a política como elemento real ou potencial ineliminável. Poderemos compreender isso melhor se observarmos que, nessa acepção ampla, política em Gramsci é sinônimo de 'catarse' [...], uma classe social, se não é capaz de realizar essa 'catarse', não pode se tornar classe 'nacional', representante dos interesses de um bloco histórico majoritário, e, desse modo, não pode conquistar a 'hegemonia' na sociedade $^{5}$ (COUTINHO, 1999, p. 90-91).

Repare que a política em sentido amplo é contida em todas as esferas do ser social de forma ineliminável. O que é claramente uma abertura para a ontopositividade da política e o esquecimento do econômico como fundante do ser social, de acordo com o pensamento marxiano e com o ser em $\mathrm{si}^{6}$.

O conceito de catarse é tido como presente não só na política em sentido amplo, mas em toda forma de práxis, desde que envolva a passagem da "recepção passiva do mundo", da "manipulação imediata", para a "esfera da totalidade" da modificação do real (COUTINHO, 1999, p. 92).

A política em sentido restrito é constituída pela grande política, que "compreende as questões ligadas à fundação de novos Estados, com a luta pela destruição, defesa e conservação de determinadas estruturas orgânicas econômico-sociais", e pela pequena política, a "do dia a dia, parlamentar, de corredor, de intriga [...] [das] questões parciais e cotidianas, que se colocam no interior de uma estrutura já estabelecida” (COUTINHO, 1999, p. 92). A grande política pode ser um espaço de manifestação da catarse, já a pequena política está limitada pela práxis manipulatória, pelo determinismo. Para Coutinho (1999, p. 93), mais uma vez Gramsci 
identificaria um aspecto ontológico fundamental do ser social ao tratar da política: o ser social "é resultado da articulação de determinismo e liberdade, de causalidade e dever-ser".

A conclusão é que a política em sentido amplo, como "catarse", é um momento inerente e ineliminável do ser social, e a política em sentido restrito é algo "historicamente transitório" (COUTINHO, 1999, p. 97). A política em sentido restrito tem um caráter histórico, pois vem à luz com o surgimento da divisão da sociedade em classes, com governantes e governados, dirigentes e dirigidos, e deverá desaparecer com o desaparecimento da sociedade cindida em classes, com o advento da sociedade regulada, comunista:

Do mesmo modo como, nessa 'sociedade regulada', os organismos sociais deverão absorver a economia (no sentido de subordinar suas leis espontâneas e aparentemente naturais ao controle consciente e programado dos produtores associados) assim também - pensa Gramsci - tais organismos deverão absorver o Estado (a sociedade política), pois as funções desse 'corpo separado' se dissolverão nas relações conscientes e consensuais que caracterizam a sociedade civil (COUTINHO, 1999, p. 94).

Coutinho (1999, p. 97) esforça-se em demonstrar que Gramsci não põe a política acima da economia e, portanto, mantém-se de acordo com a ontologia marxiana. Retomando o momento de "catarse", ele lembra que este processo ocorre "no interior de determinações econômico-objetivas que limitam (mas sem anular) o âmbito de atuação da liberdade". Ou seja, a "catarse" é uma "teleologia do movimento da causalidade econômica". O mesmo valendo para a política em sentido restrito, tanto para a determinação econômica de cada ação política singular (por exemplo, na análise da correlação de forças) quanto para a determinação da política em geral, pela economia. Pois o surgimento da política em sentido restrito e sua absorção (aufhebung) pela sociedade comunista dependem, em última instância, da economia como relação social.

Da relação entre economia e política, Coutinho (1999, p. 99) retira uma conclusão ousada:

[...] se ao processo de socialização da produção econômica corresponde um tendencial 'recuo das barreiras naturais', um maior âmbito de liberdade em face da coerção das leis naturais, a correspondente socialização da política implica o que poderíamos chamar de 'recuo (tendencial) das barreiras econômicas', com a consequente ampliação da autonomia e do poder determinante da esfera política sobre o conjunto da vida social. Quanto mais se ampliar a socialização da política, quanto mais a sociedade civil for rica e articulada, tanto mais os processos sociais serão determinados pela teleologia (pela vontade coletiva organizada) e tanto menor se imporá a causalidade automática e espontânea da economia.

Este trecho tenta fixar a ideia de que o modo como as esferas da economia e da política se articulam não é imutável e dado de uma vez por todas. Será o tipo de formação social que explicará a articulação entre as esferas e "o maior ou menor poder de determinação em sua ação recíproca" (COUTINHO, 1999, p. 100). A socialização política é condicionada, em última instância, pela socialização da produção, pela economia. Ou seja, o papel econômico de uma catástrofe natural (seca, enchente etc.) é diferenciado no caso de uma forma de sociabilidade pouco desenvolvida (selvagens primitivos) em relação à outra na qual a socialização da produção propiciou recursos tecnológicos para amenizar os efeitos da catástrofe natural. Podemos pensar, ainda, que a determinação da esfera econômica numa forma de sociabilidade na qual a sociedade civil é fluida e amorfa é diferente de uma sociabilidade na qual a sociedade civil é sólida e desenvolvida, em que se interpõe entre a esfera econômica e a esfera política e promove o recuo das barreiras econômicas.

\section{Guerra de posições e a metapolítica de Chasin}

Pensando estas questões à luz do que discutimos no item anterior, poderíamos entender a política em sentido amplo, "catarse", como a metapolítica de Chasin. Entretanto, a ideia de que o desenvolvimento da sociedade civil, a socialização da política, leva a um recuo das barreiras econômicas, traz a questão de que a política em sentido restrito cumpre um papel no desenvolvimento da sociedade civil. Sendo assim, a diferenciação entre ambas perde o sentido, e a ontopositividade da política se expressa com toda sua força.

Marx, Engels e Lênin, ao concentraram-se na análise do Estado como um conjunto de órgãos ou aparelhos repressivos, dedicaram atenção ao momento da coerção, o que, de todo modo, estava de acordo com as realidades nas quais eles estavam inseridos. Gramsci, contemporâneo dos processos de aumento da participação política (conquista do voto universal, surgimento de grandes sindicatos, partidos de massa etc.), vai voltar sua análise para esta nova "trama privada" que, segundo Coutinho (1999, p. 125), é constituída por organismos aos quais os indivíduos aderem voluntariamente, sendo, por isso, "privados" e não caracterizados pelo uso da 
repressão. Gramsci também vai se referir a esta trama privada como "sociedade civil" e como "aparelhos privados de hegemonia". Esta nova esfera do ser social tem "leis e [...] funções relativamente autônomas e específicas, tanto em face do mundo econômico quanto em face dos aparelhos repressivos do Estado" (COUTINHO, 1999, p. 124).

Coutinho defende que Gramsci, ao tratar do Estado em sentido amplo ou integral (= ditadura + hegemonia ou coerção + consenso ou sociedade política + sociedade civil), coloca uma novidade em relação aos autores clássicos do marxismo. Agora a hegemonia é uma figura social com uma base material própria (sociedade civil), podendo se manifestar num espaço autônomo e específico. A sociedade civil, mais uma vez, é constituída pela trama das organizações (escolas, igreja, partidos, sindicatos, meios de comunicação de massa etc.) que são as produtoras e/ou difusoras das ideologias. A sociedade política é constituída pelos aparelhos repressivos de Estado que, por sua vez, são controlados pela burocracia civil e militar-policial.

Ao tratar da ideologia e comparar as sociedades de tipo ocidental (Estado ampliado) com as de tipo oriental (Estado restrito), Coutinho (1999, p. 129, grifo do autor) argumenta que Gramsci promove mais um exemplo de integração da práxis política na ontologia marxiana, pois nas primeiras a esfera ideológica

[...] ganhou uma autonomia 'material' (e não só funcional) em relação ao Estado em sentido restrito. Em outras palavras: a necessidade de conquistar o consenso ativo e organizado como base para a dominação - uma necessidade gerada pela ampliação da socialização da política - criou e/ou renovou determinadas objetivações ou instituições sociais, que passaram a funcionar como portadores materiais específicos (com estrutura e legalidade próprias) das relações sociais de hegemonia. E é essa independência material - ao mesmo tempo base e resultado da autonomia relativa assumida agora pela figura social da hegemonia - que funda ontologicamente a sociedade civil como uma esfera própria, dotada de legalidade própria, e que funciona como mediação necessária entre a estrutura econômica e o Estado-coerção.

Assim a função social (hegemonia), ganha uma base material (sociedade civil), que agora é parte constitutiva do Estado ampliado. O modo como um Estado no sentido ampliado apresenta um perfil em que predomina o consenso sobre a coerção e vice-versa, vai depender: da autonomia relativa das esferas constitutivas da sociedade civil e política; do grau de socialização da política que a sociedade possui; e da correlação de forças entre as classes em luta pela hegemonia, a supremacia como síntese do domínio (coerção) e da direção intelectual e moral (consenso).

Nas formações sociais em que ocorre o Estado em sentido ampliado, Coutinho (1999, p. 134) entende que é possível que as ideologias "das classes subalternas obtenham a hegemonia no interior de um ou de vários aparelhos hegemônicos privados, mesmo antes que tais classes tenham conquistado o poder de Estado em sentido estrito, ou seja, tenham se tornado classes dominantes". E justifica tal afirmativa com a seguinte citação de Gramsci:

[...] um grupo social pode e mesmo deve ser dirigente [hegemônico] já antes de conquistar o poder governamental; uma possibilidade que, aliás, no quadro das sociedades complexas, onde o Estado se 'ampliou', torna-se também necessidade, já que - prossegue Gramsci - essa é uma das condições principais para a própria conquista do poder.

Nesse momento, começa a ficar nítida a visão de Coutinho de uma estratégia Gramsciana para o socialismo: guerra de posições. A conquista do poder de Estado nas sociedades de tipo ocidental exige uma longa luta pela hegemonia na e através da sociedade civil, ou seja, no interior do próprio Estado. Adiante voltaremos a tratar criticamente esta perspectiva. Por ora é preciso concluir os traços gerais da visão de Coutinho sobre alguns pontos-chave do pensamento de Gramsci.

A exposição de Coutinho identifica em Gramsci uma nova concretização superadora dos clássicos do marxismo, quando este trata da questão do Estado na sociedade comunista (sociedade regulada, na linguagem cifrada de Gramsci). Assim, Gramsci entendia a extinção do Estado como extinção progressiva dos aparelhos de coerção, seria a reabsorção da sociedade política pela sociedade civil. É como se as funções de dominação e coerção saíssem de cena com o avanço gradual rumo à sociedade regulada e em seu lugar predominasse a hegemonia, o consenso. Assim, para Coutinho (1999, p. 138):

O elemento Estado-coerção - diz Gramsci - pode ser imaginado como capaz de se ir exaurindo à medida que se afirmam elementos cada vez mais numerosos de sociedade regulada (ou Estado ético ou sociedade civil). Por outro lado, essa reabsorção do Estado pela sociedade civil - o fim da alienação da esfera política - ligase a uma preocupação básica revelada por Gramsci: a de que a divisão entre governantes e governados, 
entre dirigentes e dirigidos, que ele reconhece necessária em determinado nível da evolução social (no qual exista não só a divisão da sociedade em classes, mas inclusive um certo grau de divisão técnica do trabalho), não seja considerada como uma 'perpétua divisão do gênero humano', mas apenas [como] um fato histórico, correspondente a certas contradições. Torna-se assim necessário criar as condições nas quais desaparece a necessidade dessa divisão [entre governantes e governados].

Em resumo, segundo Coutinho, Gramsci entende que o fim do Estado é o fim do Estado-coerção, da sociedade política e logicamente da política em sentido restrito. Mas a sociedade civil e sua trama permanecem (!) e são, então, a base material do autogoverno da humanidade ${ }^{7}$. Logo, o fim do Estado não é o fim do governo! A sociedade está, então, condenada a viver com governantes e governados...

Voltando à questão do tipo de estratégia política para a construção da sociedade regulada, conforme Gramsci, voltamos às ideias de sociedade oriental versus ocidental. Agora o tipo de formação social irá determinar o tipo de estratégia revolucionária. Na formação de tipo ocidental, as batalhas constitutivas da guerra deverão ocorrer no seio da sociedade civil e se destinam à conquista de espaço e de posição na trama da sociedade civil, à conquista da direção política e ideológica, do consenso, da maioria da população. Isto é pré-requisito para a conquista do núcleo duro do Estado (aparelhos repressivos, executores da coerção) e para a conservação do poder. Logo, a estratégia é da guerra de posição, prolongada, cercando e desgastando o inimigo.

Já nas formações orientais, o papel ocupado pela coerção, pelo Estado restrito, e a fluidez da sociedade civil, exigem um tipo de luta que ataque frontalmente e de forma rápida o aparelho coercitivo do Estado, a sociedade política. É o caso da estratégia da guerra de movimento ou, como Gramsci a associa, da revolução permanente defendida por Marx, Engels e Trotsky. Esta estratégia visava não só a conquista do aparelho de Estado, mas também a sua posterior conservação.

A nova estratégia proposta por Gramsci, de conquista da hegemonia, guerra de posição, segundo Coutinho (1999, p. 149), é devida às diferenças simultâneas (sincrônicas) entre formações de tipo ocidental e oriental e às diferenças dinâmicas, endógenas às sociedades que estão em processo de ocidentalização. A guerra de movimento, então, seria aplicada: ao caso de formações orientais, de predomínio da coerção, de "Estados absolutos ou despóticos"; e nos casos em que há um "Estado liberal elitista" com uma sociedade civil pouco desenvolvida, como na Europa até 1870.

Coerente com sua construção teórico-metafórica, Gramsci vai redefinir o papel das crises econômicas nos processos revolucionários, na desagregação do bloco histórico dominante ${ }^{8}$ e na estratégia da guerra de posição. Nas formações ocidentais, as crises econômicas, mesmo as mais catastróficas, não têm por desdobramento uma crise generalizada da formação social porque a sociedade civil, com sua trama desenvolvida, absorve os impactos da crise econômica, funciona como "trincheiras" da guerra de posição. Logo, nestas formações, a crise revolucionária envolve outros níveis de contradições e outros tipos de articulações, para além dos colocados pela crise econômica. Sua solução, pelas forças questionadoras do status quo, exige um longo período histórico no qual deve ocorrer a de-

Assim, Coutinho passa a crer que todo processo de superação do capital e de sua lógica é dado pela política, pela expansão da democracia, pela democracia como valor universal e, como vimos, tal perspectiva só pode alimentar ilusões desastrosas para o evolver da humanidade. sagregação do bloco histórico então dominante. A crise revolucionária nas formações ocidentais é chamada por Gramsci de "crise orgânica".

Segundo Coutinho (1999, p. 153), "se a 'crise orgânica', em seu aspecto econômico, apresenta-se como manifestação de contradições estruturais do modo de produção, ela aparece - no aspecto superestrutural, político-ideológico - como crise de hegemonia". Então, a crise de hegemonia - enquanto expressão políticaideológica da crise econômica - incidirá por um longo período durante o qual as classes em luta buscarão manter ou conquistar a hegemonia na formação social, haverá avanços e recuos ao largo deste período. Por consequência, ela afasta de imediato a revolução explosiva, o putsch, o golpe de Estado, e abre espaço para a revolução processual. Mas o desfecho da luta não está dado a princípio. O bloco dominante pode, no curto prazo, utilizar-se da coerção para manter-se dominante e, no médio prazo, conseguir reorganizar seu bloco via concessões, cooptação de lideranças, corrupção etc. E nesta tarefa pode ser ajudado pela fragilidade das forças sociais antagônicas que se mostrem incapazes de propor caminhos que conquistem a direção política- 
ideológica da maioria da população. Ou ainda, as classes contestadoras podem consolidar novas alianças, conquistar o consenso, a hegemonia na sociedade civil e se tornarem classe dirigente, classe dominante. $\mathrm{Ou}$ seja, tornarem-se dirigentes dos aliados antes de tomarem o poder do Estado restrito, quando então tornar-seão classe dominante. Logo, para uma classe ser dirigente ela precisa ir além das questões corporativas, deve vir a ser classe nacional com propostas para a resolução dos problemas da Nação.

Deduz-se que a resolução da crise de hegemonia, implicada na extinção da formação social que melhor expressa a lógica do capital, só pode ser resultado da ação de "sujeitos coletivos" (COUTINHO, 1999, p. 155) que façam política envolvendo a maioria da população na solução de seus problemas, que lutem para conquistar posições na sociedade civil etc. Ou seja, a resolução da crise de hegemonia se dá com guerra de posição e revolução processual.

O sujeito coletivo, o agente que vai encarnar a "vontade coletiva transformadora" é o moderno príncipe para Gramsci, é o partido político. Ao discutir o papel do partido e suas funções, Gramsci mantém-se próximo ao desenvolvimento teórico de Lênin. Em ambos, a principal função do partido é permitir que a classe trabalhadora vá além das questões econômicas, corporativas-sindicais. Para tanto, ele vai oferecer os elementos organizativos e teóricos que possibilitam uma elevação do nível de consciência de "classe em si" para "classe para si". Assim, a classe trabalhadora estaria em condição de tomar iniciativas políticas voltadas para o conjunto dos problemas da nação. Seria a manifestação de uma vontade coletiva nacionalpopular, conforme Coutinho, lembrando ainda que o partido "aparece como uma objetivação fundamental do que Gramsci chama de 'momento catártico'; não é casual, por exemplo, que ele afirme explicitamente que, "nos partidos, a necessidade se torna liberdade". Conclui que, sendo o partido um organismo "catártico", universalizante, "cada pessoa individual - ao ingressar no partido - realiza total ou parcialmente esse momento, capacitando-se a atuar de modo mais livre e mais consciente na sociedade em que vive". Ao partido político cabe construir a "vontade nacional popular", só com ela pode-se constituir "um novo bloco histórico revolucionário, em cujo seio a classe operária (liberta de corporativismo) assuma o papel de classe dirigente". Para a constituição da vontade coletiva, ele deve compreender e considerar os "resultados espontâneos das massas. Esses sentimentos [...] [segundo Gramsci] devem ser 'educados, purificados, orientados', mas nunca ignorados". Ao considerá-los, o partido deve realizar a síntese entre o sentimento das massas e a direção política consciente (COUTINHO, 1999, p. 169-172).

Mas a formação da vontade coletiva está imbricada na reforma intelectual e moral, na revolução cultural-ideológica. A luta pela hegemonia antes da conquista do núcleo duro do Estado, ou seja, a conquista do consenso tem, na esfera da cultura, da direção ideológica, seu ponto básico. Será a difusão de uma nova cultura fundada no que de melhor a cultura do passado produziu, mas sob a lógica humano-societária do trabalho, que permitirá a criação das condições da consolidação de uma nova hegemonia. Esta reforma intelectual e moral será decisiva para a superação da divisão entre trabalho manual e intelectual, para a criação do autogoverno dos produtores livremente associados.

Por fim, registre-se o papel de destaque que Gramsci dá aos intelectuais na formação e constituição do partido político em função da relevância da reforma intelectual e moral.

\section{Considerações finais}

As construções teóricas anteriormente descritas e atribuídas a Gramsci, apresentam algumas dificuldades que precisam ser ressaltadas.

Em primeiro lugar, de acordo com Anderson (1986), a teoria dualista de poder da sociedade burguesa não abarca o conjunto de coações econômicas diretas que os explorados sofrem nela, pois não se trata nem de coerção nem de consentimento.

Em segundo lugar, na democracia burguesa, o Estado representativo é o principal mecanismo de obtenção de consenso, pois se apresenta como representante do conjunto da população, constituída de indivíduos em condições materiais desiguais, mas que formalmente são igualados perante o Estado. O Parlamento é a expressão soberana da vontade dessa totalidade da população, formalmente igual e realmente desigual, e surge aos olhos dela como seu próprio governo. Assim, consolida-se a separação entre governo e população, sendo a política a expropriação do indivíduo de sua possibilidade de autorrealização. Em resumo, o Estado democrático-representativo é a base para todos os outros aparatos ideológicos da obtenção do consenso. Logo, é equivocado situar o consenso na sociedade civil e a coerção na sociedade política, pois se a coerção é da sociedade política, o consentimento é de ambas. A inter-relação entre consenso e coerção nas formações de tipo ocidental é o que traz maior relevância para a análise. O que permite o funcionamento normal do metabolismo destas formações, com a subordinação ideológica das classes exploradas, é a coer- 
ção, o monopólio estatal da violência. Sem coerção, o consenso se fragiliza e já não há limites de ações contra ele. Como exemplo, vide a atitude dos tipógrafos nas Revoluções Russa e Cubana, em que eles acrescentavam informações e desmentidos aos artigos dos jornais que atacavam o processo revolucionário. Com a presença da coerção, o consenso pode até aparentemente existir sem ela, ou, como expõe com clareza Anderson (1986, p. 42):

O poder capitalista pode [...] ser visto como um sistema topológico com um centro 'móvel': em toda crise, assiste-se a um deslocamento objetivo e o capital, deixando de lado seus aparelhos representativos, se reconcentra em torno dos seus aparelhos repressivos. [...] Esta é uma lei do capitalismo que não pode ser violada, sob pena de morte. É a regra de uma situação de fim de jogo, de decisão final.

Em terceiro lugar, retomando a distinção de Gramsci (1989, p. 75) entre Oriente e Ocidente:

No Oriente, o Estado era tudo, a sociedade civil era primordial e gelatinosa; no Ocidente, havia entre o Estado e a sociedade civil uma justa relação e em qualquer abalo do Estado imediatamente descobria-se uma poderosa estrutura da sociedade civil. O Estado era apenas uma trincheira avançada, por trás da qual se situava uma robusta cadeia de fortalezas e casamatas; em medida diversa de Estado para Estado, é claro, mas exatamente por isto exigia um acurado reconhecimento do caráter nacional.

Aqui fica claro que Gramsci supõe que as formações sociais do leste e oeste estão na mesma temporalidade "e podem por isso ser opostas uma à outra, como variações da mesma categoria [...] sua premissa não estudada é que o Estado é o mesmo 'tipo de entidade' em ambas. Mas esta suposição 'natural' era [...] o que precisava ser questionado" (ANDERSON, 1986, p. 49, grifos do autor). Segundo Anderson, Gramsci não percebeu que o absolutismo russo era associado a um Estado feudal, o que era completamente diferente da situação da Europa Ocidental.

Uma outra questão é que mesmo com toda sua ortodoxia manifesta, Gramsci não articula a guerra de posição à guerra de movimento. Lênin, nas suas polêmicas com Martov (ANDERSON, 1986, p. 65), já advogava esta articulação. Aí a guerra de posição é a fase da disputa do consenso para a obtenção da sociedade autorregulada, e se coloca antes da fase em que o príncipe moderno dirigirá um movimento coercitivo contra o núcleo duro do Estado político. A hegemonia seria exercida no bloco histórico revolucionário dos explorados e a coerção aplicada aos exploradores com a destruição do aparelho estatal que garantia seu antigo status quo. A inexistência desta articulação no pensamento de Gramsci possibilita sua apropriação por posições teóricas reformistas e limitadas ao horizonte do capital, o que está muito longe das posições originais deste pensador.

A proposta de Coutinho, de completar a ontologia de Lukács com a introdução da política a partir da sua interpretação de Gramsci, demonstra que ele não aceita a articulação entre indivíduo e tendencialidade do ser social, conforme proposto por Lukács. Continua a ver neste constructo um determinismo e economicismo que precisaria ser eliminado. Mas, ao dar centralidade à política no ser social, ele traz uma perspectiva inteiramente positiva da mesma e entra em rota de colisão com o ser social em si e com as construções teóricas de Marx, que confirmam a negatividade da política e apontam que se o homem é um ser social ele atua em condições dadas, independentes de sua vontade. É a liberdade de escolha em meio à condicionalidades dadas. Assim, Coutinho passa a crer que todo processo de superação do capital e de sua lógica é dado pela política, pela expansão da democracia, pela democracia como valor universal e, como vimos, tal perspectiva só pode alimentar ilusões desastrosas para o evolver da humanidade.

O questionamento da lógica do capital exige um outro movimento que a confronte em seu próprio campo de produção e reprodução das condições materiais da vida humana, pois, conforme demonstra Mészáros (2002), o capital é também uma forma incontrolável de controle sociometabólico, na qual o Estado surge como uma totalidade corretora das contradições colocadas pela lógica expansiva e reprodutiva do capital, de tal forma que Estado e capital são as duas faces de um mesmo fenômeno. Portanto, só podem ser superados como surgem na história da humanidade: em conjunto e ao mesmo tempo.

Concluímos que a proposta de Coutinho - separar a grande da pequena política; introduzir o conceito de catarse; defender a extinção da pequena e a permanência da grande e catártica política - só pode ser aceita e pensada como metapolítica, como política que nega a própria política, nos termos propostos por Chasin. A sua analogia, que diz existir um afastamento das barreiras econômicas pelo avanço da política, pela complexificação da sociedade civil e da democracia, só pode ser aceita se entendermos o avanço da socialização da política como desaparecimento da própria política. Do contrário, estaríamos presos à existência permanente de dominantes e dominados, diante de um poder alienado do próprio homem. Daí porque não é aceitável a proposição 
de que na sociedade regulada desaparece o Estado-coerção e permanece o Estado-consenso, pois permanecendo o Estado-consenso, a divisão entre governantes e governados se eterniza. Ao contrário do que acredita Coutinho, a superação do capital e de sua lógica exige o fim do Estado e a constituição de uma sociedade sem governo. É tarefa da humanidade, no alvorecer de sua história, colocar fim à divisão entre governantes e governados que inviabiliza o desenvolvimento de toda a potencialidade do indivíduo humano.

\section{Referências}

ANDERSON, P. As antinomias de Antonio Gramsci. In: ANDERSON, P. et al. Crítica marxista: a estratégia revolucionária na atualidade. São Paulo: Joruês, 1986, p. 7-74.

CHASIN, J. Marx: estatuto ontológico e resolução metodológica. In: TEIXEIRA, F. J. S. Pensando com Marx. São Paulo: Ensaio, 1995, p. 335-537.

. Rota e prospectiva de um projeto Marxista. Revista Ensaios Ad Hominem. São Paulo: Edições Ad Hominem, n. 1, tomo III, p. $5-78,2000$.

COUTINHO, C. N. Lukács, a ontologia e a política. In: ANTUNES, R.; REGO, W. L. (Org.). Lukács: um Galileu no século XX. São Paulo: Jinkings, 1996, p. 16-26.

. Gramsci: um estudo sobre seu pensamento político. Rio de Janeiro: Civilização Brasileira, 1999.

GRAMSCI, A. Concepção dialética da história. Tradução de Carlos Nelson Coutinho. Rio de Janeiro: Civilização Brasileira, 1989.

LUKÁCS, G. Per una ontologia dell'essere sociale. Roma: Riuniti, 1976. ( v. I).

Per una ontologia dell'essere sociale. Roma: Riuniti, 1982. (v. II).

MARX, K. Para a crítica da economia política. Introdução de Jacob Gorender. Tradução de Edgard Malagodi, Leandro Konder, José Arthur Giannotti e Walter Rehfeld. São Paulo: Nova Cultural, 1986. (Coleção Os Economistas).

. Para a crítica da filosofia do direito de Hegel - Introdução. Tradução de Rubens Enderle e Leonardo de Deus. São Paulo: Boitempo, 2005.

MÉSZÁROS, I. Para além do capital. Tradução de Paulo Cezar Castanheira e Sérgio Lessa. São Paulo: Boitempo, 2002.

\section{Notas}

1 Registre-se que Mészáros (2002) defende que Marx define a política de forma predominantemente negativa. No capítulo intitulado Como poderia $o$ Estado fenecer, ele corrobora a construção interpretativa de Chasin, ainda que pareça desconhecê-la.

2 Sobre a validade atual do proletariado como personificação histórica da revolução social, remetemos a Chasin, (2000, p. 64-67).

3 Considerações sobre ética e política na perspectiva da ontonegatividade podem ser encontradas em Chasin (2000).

4 "Ao identificar a natureza da força política como 'força social pervertida e usurpada', socialmente ativada como estranhamento por debilidades e carências intrínsecas às formações sociais contraditórias, pois ainda insuficientemente desenvolvidas e, por consequência, incapazes de autor regulação puramente social, nas quais, pela fieira dos sucessivos sistemas sociais, quanto mais o estado se entifica real e verdadeiramente, tanto mais é contraditório em relação à sociedade civil e ao desenvolvimento das individualidades que a integram" (CHASIN, 1995, p. 368).

5 "Pode-se empregar a expressão 'catarsis' para indicar a passagem do momento puramente econômico (ou egoísta-passional) para o momento ético-político, isto é, a elaboração superior da estrutura em superestrutura na consciência dos homens. Isto significa, também, a passagem do 'objetivo ao subjetivo' e da 'necessidade à liberdade'. A estrutura da força exterior que subjuga o homem, assimilando-o e tornando-o passivo, transforma-se em meio de liberdade, em instrumento para criar uma nova forma ético-política, em fonte de novas iniciativas. Afixação do momento 'catártico' torna-se assim, creio, o ponto de partida de toda a filosofia da práxis; o processo catártico coincide com a cadeia de sínteses que resultam do desenvolvimento dialético" (GRAMSCI, 1989, p. 53).

6 Em outro texto, Coutinho (1996, p. 23) propõe-se a completar a Ontologia do ser social, de Lukács, acrescentando o que acredita ser o grande ausente deste constructo teórico: a política. Aí fica patente que seu entendimento de política envolve qualquer atividade do indivíduo humano, logo, o ser humano é entendido como um ser político, eliminando os desvios deterministas ainda presentes na concepção do velho Lukács. Coutinho discorda da forma como Lukács explica que o ser humano tem liberdade na tomada de decisões, mas esta liberdade está condicionada por condições que independem da vontade do indivíduo que decide. Ainda que suas decisões contribuam para estes condicionamentos, em geral, não ocorrem da maneira como o indivíduo espera que ocorram.

7 'O ponto novo, a concretização gramsciana da teoria ‘clássica' do fim do Estado, reside em sua ideia-realista! - de que aquilo que se extingue são os mecanismos do Estado-coerção, da sociedade política, conservando-se, entretanto, os organismos da sociedade civil, que se convertem nos portadores materiais do 'autogoverno dos produtores associados'. O fim do Estado não implica nele a ideia - generosa, mas retórica - de uma sociedade sem governo" (COUTINHO, 1999, p. 141).

8 Coutinho(1999,p. 153) entende que Gramsci utiliza o conceito de "bloco histórico" de duas formas diferentes, mas interligadas de forma dialética. Por um lado é "a totalidade concreta formada pela articulação da infraestrutura material e das superestruturas político-ideológicas [e por outro] 
uma aliança de classes sob a hegemonia de uma classe fundamental no modo de produção, cujo objetivoé conservar ou revolucionar uma formação econômico-social existente". Ainterligação dialética ocorre quando “a construção de um 'bloco histórico', no segundo sentido, implica a criação de uma nova articulação entre economia e política, entre infraestrutura e superestrutura".

\section{Paulo Henrique Furtado de Araujo}

phfurtadoa@gmail.com

Doutor em Ciências Sociais em Desenvolvimento, Agricultura e Sociedade pela Universidade Federal Rural do Rio de Janeiro (Ufrrj)

Professor da Faculdade de Economia na Universidade Federal Fluminense (UFF)

\section{UFF - Faculdade de Economia}

Rua Tiradentes, 17, sala 301

Ingá

Niterói - Rio de Janeiro - Brasil

CEP: 24210-510 